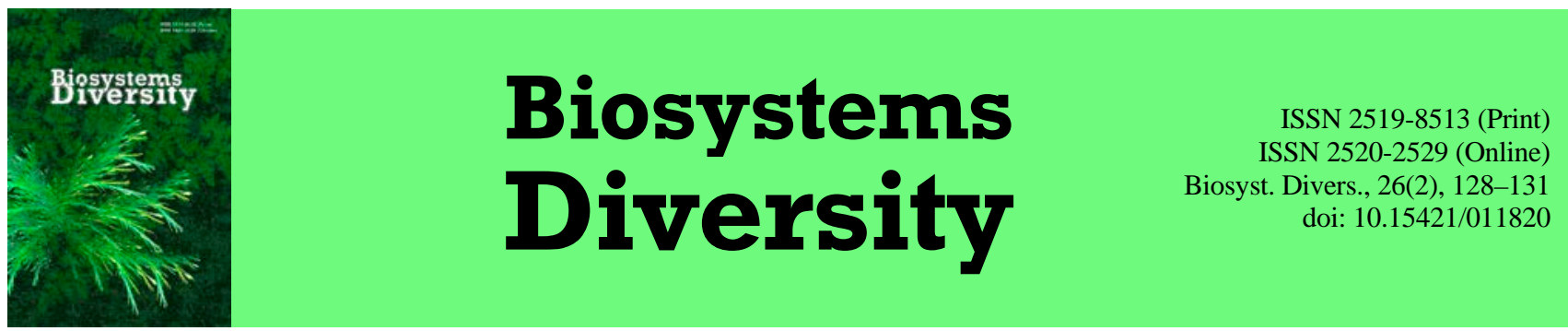

\title{
Impact of cadmium and lead on Megaphyllum kievense (Diplopoda, Julidae) in a laboratory experiment
}

\author{
V. M. Kozak, V. V. Brygadyrenko \\ Oles Honchar Dnipro National University, Dnipro, Ukraine
}

Article info

Received 11.03.2018

Received in revised form 08.05.2018

Accepted 11.05.2018

Oles Honchar Dnipro National University, Gagarin Ave. 72,

Dnipro, 49010, Ukraine. Tel.: +38-050-93-90-788. E-mail: brigad@ua.fm

\section{Introduction}

Lead and cadmium are among the most hazardous environmental pollutants, which affect the death rate of living organisms, their body weight and physiological activity of different systems of organs (Spehar et al., 1978; Dallinger, 1993; Santana et al., 2005; Valko et al., 2005; Zygmunt et al., 2006).

The average content of cadmium in the earth's crust is $130 \mathrm{mg} / \mathrm{t}$, and about thousand times lower in sea water $(0.11 \mathrm{mg} / \mathrm{t})$. Rocks contain cadmium mostly in the form of $\mathrm{CdS}, \mathrm{CdCO}_{3}, \mathrm{CdO}$, CdSe and $\mathrm{CdS}\left(\mathrm{H}_{2} \mathrm{O}\right)_{\mathrm{n}}$. A relatively high content of cadmium occurs in lead-zinc and copper-pyrite deposits. Global deposits of cadmium are estimated at around 560 thousand tons (according to US Geological Survey). Currently, the global production of cadmium equals around 21-24 thousand tons (the data of World Bureau of Metal Statistics). Mostly, cadmium is used as a component of soldering (for reducing the temperature of melting). Around $10 \%$ of cadmium production is processed in jewelry and low-melting alloys. Around $40 \%$ of cadmium is processed in undersealing metal products, and around $20 \%$ in making of cadmium electrodes and backup batteries (lead-cadmium and mercurial-cadmium elements). Nickel-cadmium batteries are widely used in the production of electronic devices, especially in China and countries of Southeast Asia. Most of these products become inoperable after a few years and accumulate in municipal solid waste storage sites. From there, cadmium penetrates the neighboring natural ecosystems, mostly via ground water and dust.

The average content of lead in the earth's crust is $16 \mathrm{~g} / \mathrm{t}$. In rocks, it occurs mostly in compound with silver, zinc and other metals, and is common in different types of rocks (from sedimentary to magmatic intrusive rocks). The world reserve of lead is 89 million tons (the data of US Geological Survey). World production of lead is around 3.8-5.3 mil t (the data of World Bureau of Metal Statistics). In the USA and countries of the European Union, $60-80 \%$ of is processed in the production of electric batteries. Earlier, lead was mostly used for making gasoline additives and solders. Also, lead is widely used in production of paint and pigments. After decomposition in municipal solid waste storage sites, many of these products become sources of lead contamination in ground water and surface soil.

Concentrating in different populations of animals, these metals can have a toxic effect on them. The concentration of cadmium in predatory invertebrates should increase significantly faster than in saprophages or herbivorous animals (Lindqvist et al., 1995; Maryanski et al., 2002; Lagisz, 2008). Addition of these metals to the diet of invertebrates decreases the activity of superoxide dismutase and glutathione peroxidase (Wang et al., 2015), and changes the ratio of isoforms of nonspecific esterases (Vlahovic et al., 2012), activity of alkaline phosphatase (Vlahovic et al., 2008) and other enzymes (Pedersen et al., 2007, 2008). This leads to change in the body weight (its increase or decrease), though there have been few laboratory experiments on change in the body weight of different groups of saprophages (Young \& Harvey, 1988; Valko et al., 2005).

The objective of this research was to determine the toxic dosages of lead and cadmium for Megaphyllum kievense (Lohmander, 1928), one of the most common species of millipedes in the steppe zone of Ukraine, in laboratory conditions, and also to determine the impact of leaf litter pollution with these elements on microbiological and zoogenic decomposition of leaf litter.

\section{Materials and methods}

Adult individuals of Megaphyllum kievense (Lohmander, 1928) were collected manually in a ravine forest in the north part of the steppe zone $\left(48.3564^{\circ} \mathrm{N}, 35.0651^{\circ} \mathrm{E}\right)$. The fodder substrate (leaf litter of half-decomposed leaves of Robinia pseudoacacia Linnaeus, 1753) was dried to air-dried condition, sieved (calibrated for placing 10-20 mm long fragments in the containers). Dry litter to the 
amount of 990-1010 mg was put in every container (200 ml plastic cups), uniformly moistened with $1 \mathrm{~g}$ of solution of metal in a certain concentration or distilled water in the control. The experiments used chemically pure $\mathrm{CdCl}_{2}$ and $\mathrm{Pb}\left(\mathrm{NO}_{3}\right)_{2}$. The data on concentration of pollutants in the graphs and text are given in mg of metal (Cd or $\mathrm{Pb}$ ) per $1 \mathrm{~kg}$ of dry litter. The data on fodder consumption and decrease in the mass of litter are calculated for a 24-hour period.

One $M$. kievense individual (an equal number of males and females was used for every variant of the experiment) was put in each container; average mass of individuals at the beginning of the experiment equaled $36.4 \pm 9.3 \mathrm{mg}$ ( $\mathrm{min}-19.1$, max $-70.0 \mathrm{mg})$, and at the end it was $43.5 \pm 1.3 \mathrm{mg}$ (min - 21.9, max - 76.4 mg). The total number of $M$. kievense individuals used in the experiment was 130: 6 concentrations of each of the metals $(n=10)$ and one control $(n=10)$. The litter in 130 containers with the same concentration of metals $(n=10)$ and without it $(n=10)$ was at the same time weighed for control of microbiological decomposition of the substrate. For maintaining an optimum uniform moisture of the litter, a small amount of distilled water was added to the control and experimental containers once every two days. The experiment lasted 20 days.

The data was compared using Tukey's test. Differences between the selections were considered statistically significant at $\mathrm{P}<$ 0.05. The data was analyzed in Statistica 13 (Dell Inc., USA, 2015), the small squares in the diagrams show the median, the large rectangles show the $25 \%$ and $75 \%$ quartiles, the vertical lines show $95 \%$ of the variation, the stars and circles show the outliers.

\section{Results}

The death rate of $M$. kievense increased from $10-20 \%$ to $40 \%$ at 3 and $30 \mathrm{~g} / \mathrm{kg}$ concentration of lead and to $100 \%$ at $30 \mathrm{~g} / \mathrm{kg}$ concentration of cadmium (Table 1). Gain in the body weight of $M$. kievense over the 20-day laboratory experiment reliably decreased only at $3 \mathrm{~g} / \mathrm{kg}$ cadmium ( 0.71 to $0.20 \mathrm{mg} / 24$ hours, Fig. $1 a$ ). The impact of lead caused weight gain to reliably decrease already at the concentration of $30 \mathrm{mg} / \mathrm{kg}$ of substrate $(0.74$ to $0.10 \mathrm{mg} / 24$ hours, Fig. 1b) compared to the control.

The impact of cadmium and lead caused the litter to decompose at a significantly slower rate only at the concentration of $30 \mathrm{~g}$ of metal per $1 \mathrm{~kg}$ of litter (Fig. 2). The differences in the rates of decrease in the litter mass in the presence of $M$. kievense and during the absence of the millipedes are not reliable.

\section{Discussion}

The data obtained in a previous study (Brygadyrenko \& Ivanyshin, 2014) of the change in the body weight of $M$. kievense in relation to iron concentration $\left(10^{-1}\right.$ to $10^{-8} \mathrm{mg} / \mathrm{g}$ of fodder) showed similar results: the millipedes on average gained $2.5 \mathrm{mg} / 24$ hours, the differences between high, average and low concentrations of $\mathrm{Fe}$ in the substrate were also insignificant. Copper in the diet of M. kievense caused a significant impact on the body weight of the millipedes (Brygadyrenko \& Ivanyshin, 2015): a low dose of $\mathrm{Cu}\left(10^{-8} \mathrm{mg} / \mathrm{g}\right.$ of litter) doubled the increase in weight gain, and a high concentration $\left(10^{-1} \mathrm{mg} / \mathrm{g}\right.$ of litter) decreased the weight gain threefold, i.e. toxically affected the invertebrates. Copper occurs in the compound of the enzymes, perhaps, that is why its low concentration causes anabolic changes in $M$. kievense. Iron caused no gain in body weight similarly to lead and cadmium in this recent study, where the metals did not affect the millipedes' body weight. Similar results (Shulman et al., 2017) were obtained after analyzing the trophic activity of Calliphora vicina Robineau-Desvoidy, 1830 larvae: no reliable changes in the pupa weight were found at minimum to $10^{-3} \mathrm{mg} / \mathrm{g}$ concentrations. The studies by Schmid et al. $(1991,1992)$ showed a decrease in the body weight of Aiolopus thalassinus (F.) imagoes caused by the effect of cadmium. Hatching of eggs in soil saturated with lead and cadmium significantly decreased.
Table 1

Mortality of $M$. kievense fed on litter with high concentrations of heavy metals during a 20 day experiment

\begin{tabular}{lccccccc}
\hline Chemical & \multicolumn{6}{c}{ Concentration of the metal, $\mathrm{mg} / \mathrm{kg}$ of substrate } \\
\cline { 2 - 8 } element & 0 & 0.3 & 3 & 30 & 300 & 3000 & 30000 \\
\hline Cadmium & 20 & 10 & 20 & 10 & 10 & 20 & 100 \\
Lead & 20 & 10 & 20 & 10 & 20 & 40 & 40 \\
\hline
\end{tabular}
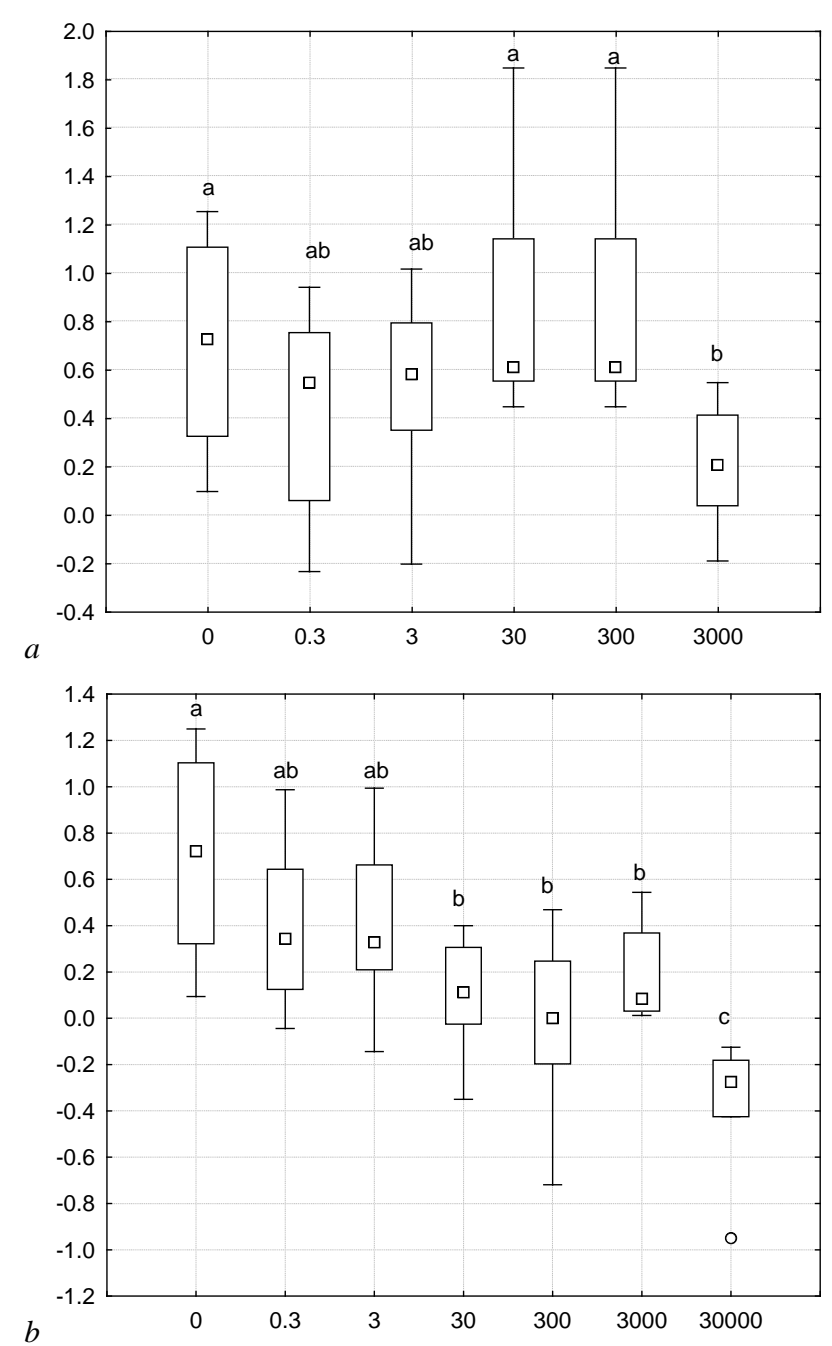

Fig. 1. Changes in the body weight of $M$. kievense during the 20-day laboratory experiment with substrate including cadmium (a) and lead (b): on the abscissa - concentration of metal in the food substrate ( $\mathrm{mg} / \mathrm{kg}$ of fodder substrate), on the ordinate - change in the body mass of $M$. kievense (mg/24 hours); n = 6-9 depending on death rate, indicated in Table 1; different letters correspond to the selections which had significant differences between one

another according to the results of Tukey's test $(\mathrm{P}<0.05)$

Cadmium at $10 \mathrm{mg} / \mathrm{kg}$ concentration has reliably decreased the formation of cocoons of Eisenia andrei Bouche earthworms (Van Gestel et al., 1993). Change in the body weight occurred among the following saprophage insects and phytophages: Orchesella cincta (L.) (Posthuma et al., 1992; Hensbergen et al., 2000), Proisotoma minuta Tullberg (Nursita et al., 2005), Chironomus riparius (Meigen) (McChaton \& Pascoe, 1991), Chironomus tentans F. (Martinez et al., 2001, 2004), Ch. thummi (Meigen) (Bisthoven et al., 1992), Tanytarsus dissimilis Johannsen (Anderson et al., 1980), Locusta migratoria (L.) (Martoja et al., 1983), Oncopeltus fasciatus (Dallas) (Cervera et al., 2004), Lymantria dispar L. (Vlahovic et al., 2008; Mircic et al., 2010, 2013), Aglais urticae (L.) (Lindqvist, 1994), Drosophila melanogaster Meigen (Maroni \& Watson, 1985; Lauverjat et al., 1989), Musca domestica L. (Niu et al., 2002). 
Change in the litter mass under the impact of copper and iron (Brygadyrenko \& Ivanyshin, 2014, 2015) in the absence of the millipedes was insignificant compared to the control. Lead and cadmium in this study at concentrations up to $3 \mathrm{~g} / \mathrm{kg}$ of litter caused no significant inhibition in the activity of the microflora which decomposes the leaf litter. Higher concentration of cadmium and lead significantly inhibited both microbiological and zoogenic decomposition of plant remains.

\section{Conclusions}

Cadmium and lead penetrates the environment over a period of decades, accumulating in the soils around large cities, thus affecting the activity of growth of saprophage millipedes. Only high concentrations (about $30 \mathrm{~g} / \mathrm{kg}$ of litter) increase the death rate and inhibit the growth of millipedes. Inhibition of litter decomposition by 3-8 times occurs also at a cadmium and lead concentration of $30 \mathrm{~g} / \mathrm{kg}$ of litter.

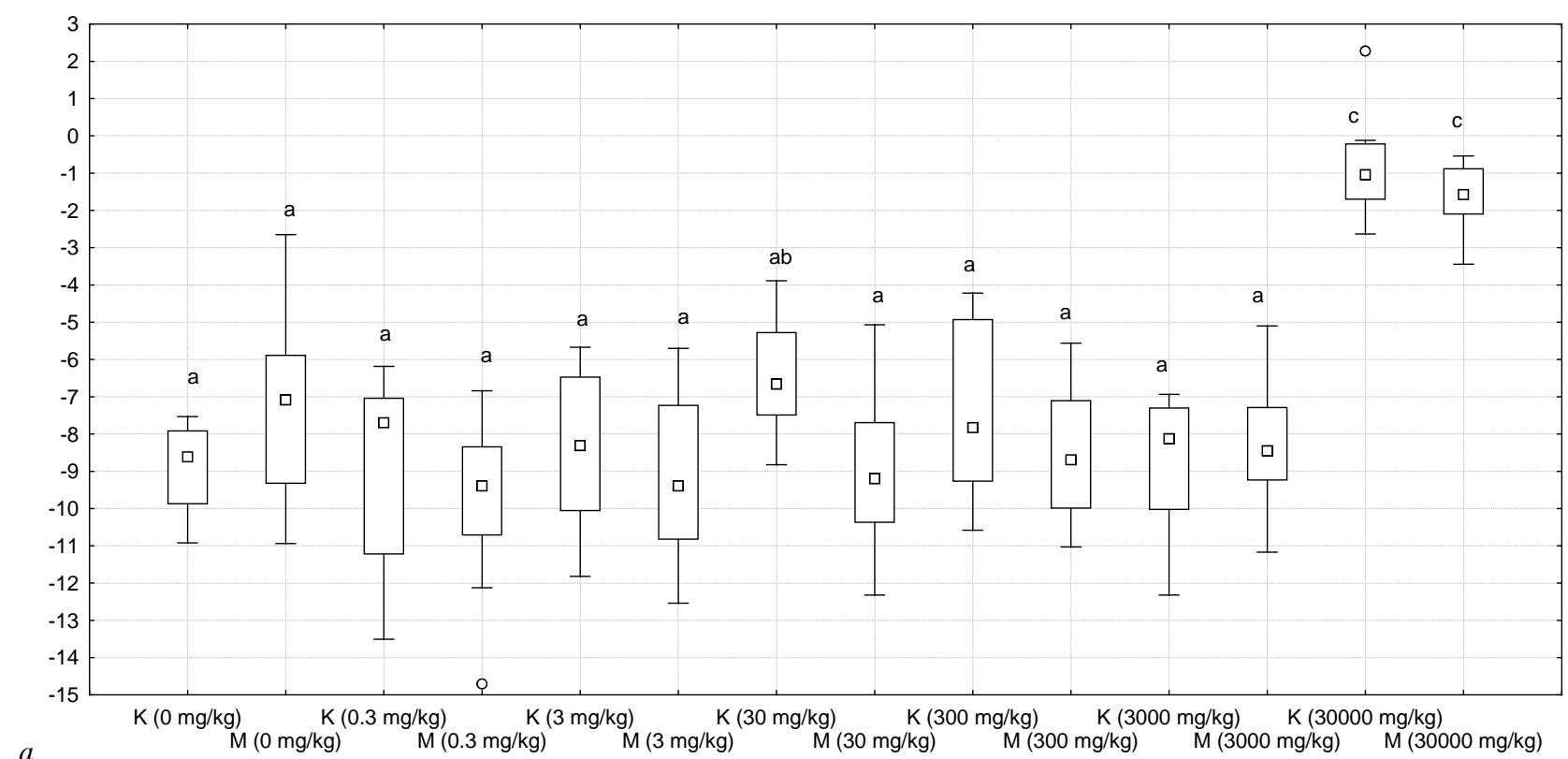

$a$

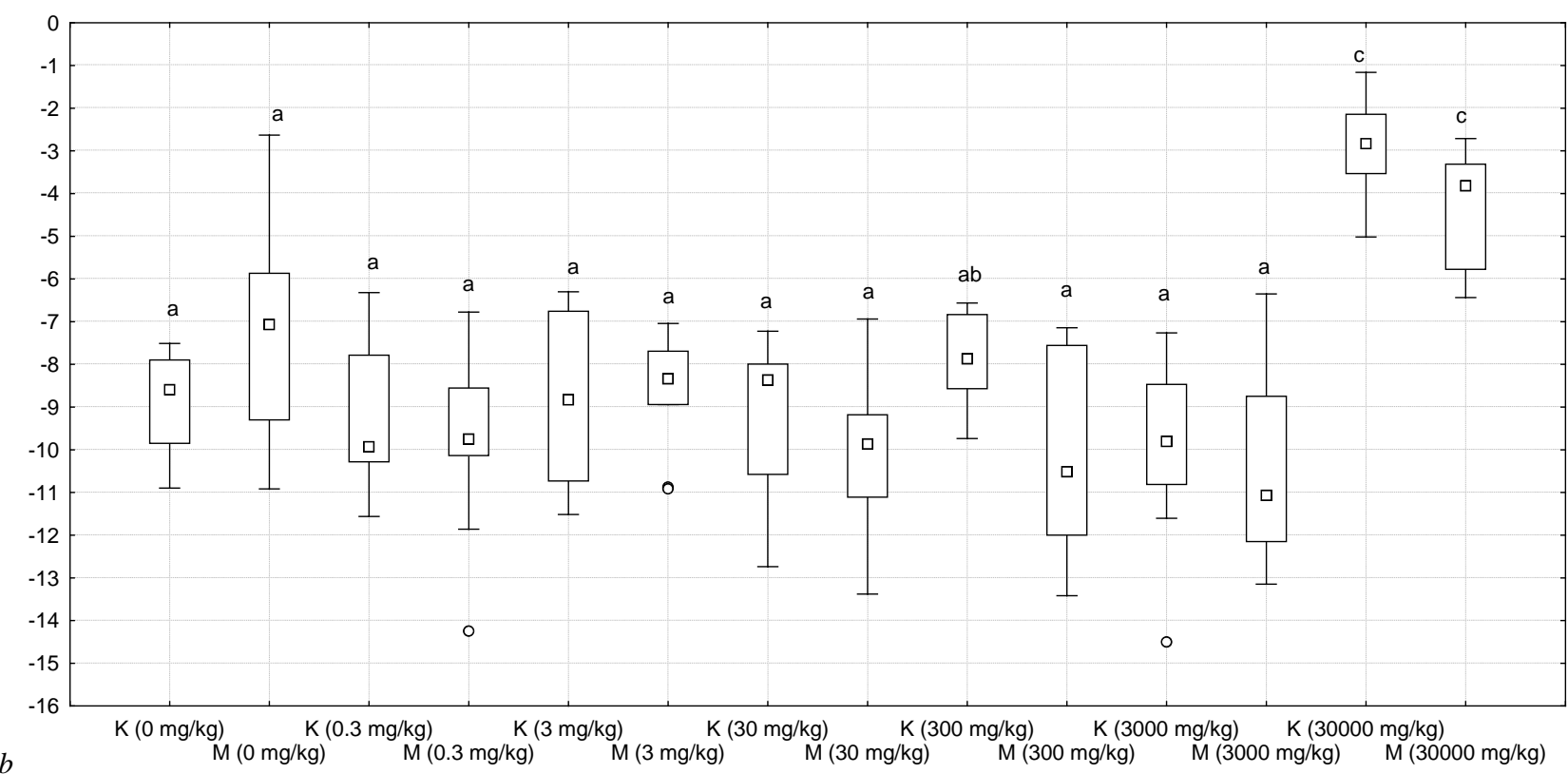

Fig. 2. Changes in the weight of food substrate including cadmium ( $a$ ) and lead (b) over a 20-day laboratory experiment:

on the abscissa - concentration of the metal in the food substrate ( $\mathrm{mg} / \mathrm{kg}$ food substrate), on the ordinate - change in weight of litter (mg/24 hours); K - variant of experiment without $M$. kievense $(\mathrm{n}=10), \mathrm{M}-$ variant of experiment with $M$. kievense $(\mathrm{n}=6-9$ in relation to death rate presented in Table 1); different letters correspond to the selections which had significant differences between one another according to the results of Tukey's test $(\mathrm{P}<0.05)$

Change in the biological activity of the microflora and of the studied species of litter invertebrate occurs at practically the same concentrations of cadmium and lead. Further research requires study of the change in the enzymic activity, the cellular composition of hemolymph and parasitic fauna of the intestine of $M$. kievense in the conditions of heightened concentrations of heavy metals.

\section{References}

Anderson, R. L., Walbridge, C. T., \& Fiandt, J. T. (1980). Survival and growth of Tanytarsus dissimilis (Chironomidae) exposed to copper, cadmium, zinc, and lead. Archives of Environmental Contamination and Toxicology, 9(3), 329-335.

Brygadyrenko, V. V., \& Ivanyshin, V. M. (2014). Impact of ferric salt on body weight of Megaphyllum kievense (Diplopoda, Julidae) and litter granu- 
lometric composition in the laboratory experiment. Visnyk of Dnipropetrovsk University. Biology, Ecology, 22(1), 83-87.

Brygadyrenko, V., \& Ivanyshyn, V. (2016). Changes in the body mass of Megaphyllum kievense (Diplopoda, Julidae) and the granulometric composition of leaf litter subject to different concentrations of copper. Journal of Forest Science, 61(9), 369-376.

Cervera, A., Maymó, A. C., Sendra, M., Martínez-Pardo, R., \& Garcerá, M. (2004). Cadmium effects on development and reproduction of Oncopeltus fasciatus (Heteroptera: Lygaeidae). Journal of Insect Physiology, 50(8), 737-749.

Chang-ying, N., Yond, J., Chao-liang, L., \& Cui, H. (2002). Effects of cadmium on housefly: Influence on growth and development and metabolism during metamorphosis of housefly. Insect Science, 9(1), 27-33.

Dallinger, R. (1993). Strategies of metal detoxification in terrestrial invertebrates. In: Dallinger, R., Rainbow, P. S. (eds.). Ecotoxicology of metals in invertebrates. Lewis Publishers, Boca Raton. Pp. 245-289.

De Bisthoven, L. G. J., Timmermans, K. R., \& Ollevier, F. (1992). The concentration of cadmium, lead, copper and zinc in Chironomus gr. thummi larvae (Diptera, Chironomidae) with deformedversus normal menta. Hydrobiologia, 239(3), 141-149.

Hensbergen, P. J., van Velzen, M. J. M., Adi Nugroho, R., Donker, M. H., \& van Straalen, N. M. (2000). Metallothionein-bound cadmium in the gut of the insect Orchesella cincta (Collembola) in relation to dietary cadmium exposure. Comparative Biochemistry and Physiology Part C: Pharmacology, Toxicology and Endocrinology, 125(1), 17-24.

Lagisz, M. (2008). Changes in morphology of the ground beetle Pterostichus oblongopunctatus F. (Coleoptera; Carabidae) from vicinities of a zinc and lead smelter. Environmental Toxicology and Chemistry, 27(8), 1744-1767.

Lauverjat, S., Ballan-Dufrancais, C., \& Wegnez, M. (1989). Detoxification of cadmium. Ultrastructural study and electron-probe microanalysis of the midgut in a cadmium-resistant strain of Drosophila melanogaster. Biology of Metals, 2(2), 97-107.

Lindqvist, L. (1994). Metal uptake and accumulation during growth of Aglais urticae (Lepidoptera: Nymphalidae) larvae. Environmental Entomology, 23, 975-978.

Lindqvist, L., Block, M., \& Tjalve, H. (1995). Distribution and excretion of $\mathrm{Cd}, \mathrm{Hg}$, methyl-Hg and $\mathrm{Zn}$ in the predatory beetle Pterostichus niger (Coleoptera, Carabidae). Environmental Toxicology and Chemistry, 14, 1195-1201.

Maroni, G., \& Watson, D. (1985). Uptake and binding of cadmium, copper and zinc by Drosophila melanogaster larvae. Insect Biochemistry, 15(1), 55-63.

Martinez, E. A., Moore, B. C., Schaumloffel, J., \& Dasgupta, N. (2001). Induction of morphological deformities in Chironomus tentans exposed to zinc- and lead-spiked sediments. Environmental Toxicology and Chemistry, 20, 2475-2481.

Martinez, E. A., Moore, B. C., Schaumloffel, J., \& Dasgupta, N. (2004). Effects of exposure to a combination of zinc- and lead-spiked sediments on mouthpart development and growth in Chironomus tentans. Environmental Toxicology and Chemistry, 23(3), 662.

Martoja, R., Bouquegneau, J. M., \& Verthe, C. (1983). Toxicological effects and storage of cadmium and mercury in an insect Locusta migratoria (Orthoptera). Journal of Invertebrate Pathology, 42(1), 17-32.

Maryanski, M., Kramarz, P., Laskowski, R., \& Niklinska, M. (2002). Decreased energetic reserves, morphological changes and accumulation of metals in carabid beetles (Poecilus cupreus L.) exposed to zinc- or cadmium-contaminated food. Ecotoxicology, 11, 127-139.

McCahon, C. P., \& Pascoe, D. (1991). Brief-exposure of first and fourth instar Chironomus riparius larvae to equivalent assumed doses of cadmium: Effects on adult emergence. Water, Air, and Soil Pollution, 60, 395-403.

Mirčić, D., Blagojević, D., Perić-Mataruga, V., Ilijin, L., Mrdaković, M., Vlahović, M., \& Lazarević, J. (2012). Cadmium effects on the fitness- related traits and antioxidative defense of Lymantria dispar L. larvae. Environmental Science and Pollution Research, 20(1), 209-218.

Mircic, D., Jankovic-Tomanic, M., Nenadovic, V., Franeta, F., \& Lazarevic, J. (2010). The effects of cadmium on the life history traits of Lymantria dispar L. Archives of Biological Sciences, 62(4), 1013-1020.

Nursita, A. I., Singh, B., \& Lees, E. (2005). The effects of cadmium, copper, lead, and zinc on the growth and reproduction of Proisotoma minuta Tullberg (Collembola). Ecotoxicology and Environmental Safety, 60(3), 306-314.

Pedersen, S. A., Kristiansen, E., Andersen, R. A., \& Zachariassen, K. E. (2007). Isolation and preliminary characterization of a Cd-binding protein from Tenebrio molitor (Coleoptera). Comparative Biochemistry and Physiology Part C: Toxicology and Pharmacology, 145(3), 457-463.

Pedersen, S. A., Kristiansen, E., Andersen, R. A., \& Zachariassen, K. E. (2008) Cadmium is deposited in the gut content of larvae of the beetle Tenebrio molitor and involves a Cd-binding protein of the low cysteine type. Comparative Biochemistry and Physiology Part C: Toxicology and Pharmacology, 148(3), 217-222.

Posthuma, L., Hogervorst, R. F., \& Van Straalen, N. M. (1992). Adaptation to soil pollution by cadmium excretion in natural populations of Orchesella cincta (L.) (Collembola). Archives of Environmental Contamination and Toxicology, 22(1), 146-156.

Sant'Ana, M. G., Moraes, R., \& Bernardi, M. M. (2005). Toxicity of cadmium in Japanese quail: Evaluation of body weight, hepatic and renal function, and cellular immune response. Environmental Research, 99(2), 273-277.

Schmidt, G. H., Ibrahim, N. M. M., \& Abdallah, M. D. (1991). Toxicological studies on the long-term effects of heavy metals $(\mathrm{Hg}, \mathrm{Cd}, \mathrm{Pb})$ in soil on the development of Aiolopus thalassinus (Fabr.) (Saltatoria: Acrididae). Science of The Total Environment, 107, 109-133.

Schmidt, G., Ibrahim, N. M., \& Abdallah, M. (1992). Long-term effects of heavy metals in food on developmental stages of Aiolopus thalassinus (Saltatoria: Acrididae). Archives of Environmental Contamination and Toxicology, 23(3), 375-382.

Shulman, M. V., Pakhomov, O. Y., \& Brygadyrenko, V. V. (2017). Effect of lead and cadmium ions upon the pupariation and morphological changes in Calliphora vicina (Diptera, Calliphoridae). Folia Oecologica, 44(1), 28-37.

Spehar, R. L., Anderson, R. L., \& Fiandt, J. T. (1978). Toxicity and bioaccumulation of cadmium and lead in aquatic invertebrates. Environmental Pollution, 15(3), 195-208.

Valko, M., Morris, H., \& Cronin, M. (2005). Metals, toxicity and oxidative stress. Current Medicinal Chemistry, 12(10), 1161-1208.

Van Gestel, C. A. M., Dirven-van Breemen, E. M., \& Baerselman, R. (1993) Accumulation and elimination of cadmium, chromium and zinc and effects on growth and reproduction in Eisenia andrei (Oligochaeta, Annelida). Science of The Total Environment, 134, 585-597.

Vlahović, M., Lazarević, J., Perić-Mataruga, V., Ilijin, L., \& Mrdaković, M. (2009). Plastic responses of larval mass and alkaline phosphatase to cadmium in the gypsy moth larvae. Ecotoxicology and Environmental Safety, 72(4), 1148-1155.

Vlahović, M., Perić Mataruga, V., Ilijin, L., Mrdaković, M., Mirčić, D., Todorović, D., \& Lazarević, J. (2011). Changes in activity of non-specific esterases in cadmium treated Lymantria dispar larvae. Ecotoxicology, 21(2), 370-378.

Wang, J., Ren, T., Han, Y., Zhao, Y., Liao, M., Wang, F., \& Jiang, Z. (2015) The effects of dietary lead on growth, bioaccumulation and antioxidant capacity in sea cucumber, Apostichopus japonicus. Environmental Toxicology and Pharmacology, 40(2), 535-540.

Zygmunt, P. M. S., Maryański, M., \& Laskowski, R. (2006). Body mass and caloric value of the ground beetle (Pterostichus oblongopunctatus) (Coleoptera, Carabidae) along a gradient of heavy metal pollution. Environmental Toxicology and Chemistry, 25(10), 2709-2714. 